\title{
Phytoremediation potential of Pteridium aquilinum and the toxicity of Nickel on Clarias gariepinus juvenile
}

\author{
1Olaifa, Flora. E. \& ${ }^{2} E$ wutanure, Somorhire J. \\ 1Department of Aquaculture and Fisheries Management, Faculty of Renewable Natural Resources, \\ University of Ibadan, Ibadan, Nigeria. \\ ${ }^{2}$ Department of Fisheries and Aquaculture Management, Faculty of Marine Environmental Management, Nigeria \\ Maritime University, Delta State, Nigeria. \\ E-mails:ewutanure@gmail.com; floraolaifa@yahoo.com \\ Phones: +2348101634482; +2348035509342.
}

\begin{abstract}
A laboratory experiment was carried out to assess the phytoremediation potential of Pteridium aquilinum and the toxicity of nickel on C. gariepinus juvenile in six treatments (TWP0, TWP1, TWP2, TWP3, TWP4, TWP5) each having two replicates in static renewable bioassay for 21 days. Pteridium aquilinum was harvested between $6-8$ am within the University of lbadan to ensure they did not dry up before reaching the laboratory. The ferns along with the soil around their roots were placed in five plastic basins of $100 \mathrm{~L}$ water - holding capacity with each containing $80 \mathrm{~L}$ of water in the laboratory for 7 days to allow the soil to gradually detach from their roots. Rhizomes having $3-5$ newly grown shoots were carefully transferred into each of the 12 glass aquaria containing the solution of the toxicant with concentrations of $10,7.5,5.6,3.2,1.8,0 \mathrm{mg} / \mathrm{L} \mathrm{Nickel}$, respectively. Ten juvenile of C. gariepinus per replicate were introduced into the test solution and the experiment was monitored for 21 days, while the fish were fed to satiation. The test solution was renewed, while water, plant, fish and blood samples were collected every 7 days for analyses according to standard procedures. Water, blood, plant and fish samples were analysed for Temperature $\left({ }^{\circ} \mathrm{C}\right)$, Dissolved Oxygen, DO $(\mathrm{mg} / \mathrm{L})$; Packed Cell Volume (PCV, \%), Red Blood Cells (RBC, $10^{6} \mathrm{~mm}^{-3}$ ); Aspartate Transaminase (AST, IU.L-1), Alanine Transaminase (ALT, IU.L-1) and Nickel $\left(\mathrm{mg}^{-L^{-1}}\right)$. Data were subjected to descriptive statistics and ANOVA at $\mathrm{a}_{0.05}$. Significantly highest (27.5 \pm 2.23$)$ and least (24.53 \pm 4.23$)$ Temperature, DO (4.56 $\pm 0.91,3.01 \pm 0.61)$, PCV (25.70 \pm 0.40 , $9.53 \pm 0.50)$ and RBC $(14.00 \pm 0.11,6.74 \pm 0.43)$ were obtained in TWP1 and TWP0, while highest $(38.54 \pm 0.50)$ and least (10.02 \pm 1.01$)$ AST and ALT $(66.54 \pm 1.50,14.54 \pm 0.16)$ were recorded in TWP1 and TWP0, respectively. Mean Nickel concentration in Water ranged from $<0.01$ to $0.21 \pm 0.01$, Plant $(<0.01,0.42 \pm 0.01)$ and Fish $(0.02 \pm 0.01$, $0.29 \pm 0.01$ ) in TWP0 and TWP1 in the order plant $>$ fish $>$ water. Due to the exposure of $C$. gariepinus juvenile to Nickel toxicity, it survival was threatened because of an increased level of ALT. Nickel concentration in water was lower in water compared with its levels in P.aquilinum and fish.
\end{abstract}

Keywords: Phytoremediation, Nickel toxicity, Toxicology, Contaminant, Blood biochemistry.

Aims Research Journal Reference Format:

Olaifa, Flora. E \& Ewutanure, Somorhire J. (2019): Phytoremediation potential of Pteridium aquilinum and the toxicity of Nickel on Clarias gariepinus juvenile. Advances in Multidisciplinary Research Journal. Vol. 5. No. 4, Pp 67-80. Available online at https://www.isteams.net/aimsjournal Article DOI: dx.doi.org/10.22624/AlMS/V5N4P7

\section{INTRODUCTION}

Phytoremediation is a simple technique used to clean up contaminated soils and water (Osman et al., 2010). It encompasses plant physiology, soil microbiology, soil and water chemistry. Phytoremediation simply refers to various combinations of plant - based technologies that use both natural and genetically improved plants for the cleaning up of polluted soil or sediment (Barac et al., 2009). 
It is known as green remediation, botano - remediation, agroremediation, or vegetative remediation (Bes and Mench, 2008). It involves the intentional usage of plants for in situ removal of contaminants in soil, sediment or surface water (Khan and Moheman, 2006). The roots are the major assimilators of pollutants or contaminants in plants (Ghazaly, 2011). The root give large surface area that take up and accumulate water and nutrients required for growth (Outridge and Scheuhammer, 2007). Due its low cost and solar energy driven strategy, phytoremediation is very important because disposal of hazardous materials is not needed, effective in mechanical clean - up, potent when rapid immobilization is needed to preserve surface water and ground water, useful in areas with shallow and low level of contamination (Bani et al., 2007). Though, the time required to achieve clean - up standards using phytoremediation may be very long for hydrophobic pollutants that are tightly bound to soil or sediment particles, its effectiveness depends on the chemical nature of the Contaminants (USEPA, 2008).

\section{Processes of phytoremediation}

Phytodegradation is equally referred to as phyto - transformation. It is the degradation of pollutants absorbed by plants root through metabolic processes within the plants with the aid of enzymes produced by the plants to enhance faster growth (Barac, 2009). These processes are (i) phytoaccumulation/phytoextraction (ii) phytorestoration (iii) rhizofiltration and (iv) phytovolatilization.

\section{Phytoaccumulation/phytoextraction}

It is concerned with the use of plants to remove contaminants from soil by accumulation in plant tissue (Alan et al., 2006). Plants absorb, translocate and store toxic contaminants (nickel, copper, and zinc) into their roots and shoot tissues (Bes and Mench, 2008). Two types of phytoextraction exist which are natural hyperaccumulation where plants naturally take up contaminants from the sediment or soil unassisted, while the second type is known as induced or assisted hyperaccumulation in which conditioning fluid containing a chelator is introduced into the soil to facilitates metal solubility or transportation so that plant roots can absorb them more rapidly (Khan et al., 2012). In many cases, natural hyperaccumulators are metallophytes that can tolerate and incorporate high levels of toxic metals (Barac,2009).

Phytorestoration/Phytostabilization is aimed at the use of plants to bind/immobilize contaminants in water and sediment matrix through their absorption into the roots and accumulation or precipitation within the root zone of plants (Osman et al., 2010). Phytorestoration enhances mobility reduction of contaminants and prevents their migration into surface and ground water, decreases bioavailabitiy of pollutants entering into food chain (FAO, 2004). It is a process that stabilizes waste and prevents exposure pathway in water (United States Public Health Service, USPHS, 2010).

According to USPHS, (2011), rhizofilteration process involves growing plants hydroponically and thereafter transplanting them into metal polluted water or sediment where plants absorb and accumulate the metals in their roots and shoots. Rhizofilteration can be used for clean - up of Lead, Cadmium, Copper, Nickel, Zinc and Chromium which are primarily retained within the roots (USEPA, 2009). Phytovolatilization is the use of plants to take up contaminants from water, sediment and soil, transforming them into volatile forms and transpiring them into the atmosphere (USEPA, 2007). It is also known as phyto - stimulation or plant assisted bioremediation or biodegradation (USPHS, 2011). It is the breaking down of contaminants in the rhizoshpere through microbial activities supported by the presence of plant roots.

\section{Biology of Nickel}

According to National Academy of Sciences, NAS, (2011) Nickel is listed as a dangerous substance and regulated through the Council of European Communities because of its toxicity, persistence, and affinity for bioaccumulation on the European Commission List II. Nickel compound is classified in group 1 as human carcinogens and as metallic nickel in group 2B (possible human carcinogen) (World Health Organisation, 2008). According to Olaifa and Ewutanure, (2018) some toxic effects of nickel in fishes include central nervous system disorders and dermatitis, haematological alteration, liver and kidney break down. 
At high concentration, nickel exerts adverse effects in fish accruing structural damage which affect growth, development and survival (Olaifa and Ewutanure, 2018). Sublethal level of nickel is known to adversely affect hatchability, survival, serum and haematological parameters of fish (USPHS, 2011). Nickel can cause both sub-acute and chronic effects that induced changes in fish behaviour (Gupta and Srivastava, 2006). Such observed induced changes include agitated swimming, lack of balance since majority of the fins are motionless, air gulping and death (Olaifa and Ewutanure, 2018). Haematological alterations have been observed in the chronic exposure of $C$. gariepinus to nickel toxicity (Olaifa and Ewutanure, 2018). Nickel accumulates in the gills of fish and this reveals a depressive effect on tissue respiration leading to fish mortality through hypoxia (USPHS, 2010).

\section{Classification, biology and ecology of P. Aquilinum}

The P. aquilinum belong to kingdom, Plant; division, Pteridophyta; Class, Filicopsida; Order, Polipodiales; Family, Dennstaedtiaceae; Genus, Pteridium; Species, Pteridium aqulinum (Alan et al.,2006). The P. aquilinum is a perennial plant occurring in dry to wet forest, sandy soils, lake shores and wetlands. The underground stems are deep giving it ability to survive intense fire. Their hardy persistent root systems help them to grow larger and thicker over time which helps them to compete effectively for nutrients with other plants. Bracken fern has multiple branching stem and triangular shaped fronds with many leaflets like segments. Bracken ferns are large ferns with erect stiff fronds sometimes growing over three feet tall. Its large triangular fronds are divided into three main parts with each part bipinnately subdivided. These fronds are $2-4$ feet long by $1-3$ feet wide (Bani et al., 2007; Barac et al., 2009).

The increase in the rates of aquatic pollution by heavy metals is alarming. The impact of clean up due to the use of chemical compounds and synthetic materials further degrade the quality of the aquatic ecosystem systems. This study was therefore aimed at the application of $P$. Aquilinum as a natural source of cleaning up polluted aquatic environment.

\section{MATERIALS AND METHODS}

The P. aquilinum were collected from the vicinity within the University of Ibadan Campus. All samples were collected and transported in polythene bags to the laboratory at $8 \mathrm{am}$ when the atmospheric temperature was low to ensure that the plants do not dry up easily. In the laboratory, the plants were placed together in plastic bowls with the soil in their roots and were were wetted continuously until the soils were flooded and the compacted soils loosened.

The soils were removed after one week by draining out the water gradually to avoid damage to the fresh plants. The plants were then acclimatized for two weeks using poultry manure at the rate of $10 \mathrm{mg} / \mathrm{L}$ (Okonji and Ewutanure, 2011) in $20 \mathrm{~L}$ of water in aquaria glass tanks. Poultry manure was used as a bio - stimulant of growth to the plants. More appropriate volume of water and poultry manure at the same rate were added to keep the water level and concentration of the organic manure constant.

\section{Chronic bioassay (21days $\mathrm{LC}_{50}$ )}

A chronic bioassay comprising six treatments with each having two replicates was set up. The experiment contained $P$. aquilinum (with $3-4$ fronds) which had been acclimatized for two weeks. Two weeks duration was allowed for the uptake of nickel. A static bioassay was used for the set up. The concentrations (10 mg.L-1, $7.5 \mathrm{mg} . \mathrm{L}^{-1}, 5.6 \mathrm{mg} . \mathrm{L}^{-1}, 3.2$ $\mathrm{mg.L} \mathrm{L}^{-1}, 1.8 \mathrm{mg.L^{-1 }}$ and TWPO (control) for the test solution were prepared according to the procedure described by Reish and Oshida, (1987). The volume of the test solution used per replicate for the experiment was 20 litre of water containing nickel (toxicant). The P. aquilinum was used because much work has not been done on its phytoremediation potentials in relation to the aquatic environment, while the duration of the experiment was 21 days. 


\section{Introduction of plants into the experimental glass aquaria tanks}

Plants stands of about 5 fronds on rhizome with $4-5$ up - coming shoots were transferred into the set of the aquaria glass tanks. Water used for the acclimatization of plants was made up to $20 \mathrm{~L}$ and was maintained throughout the experimental period using the University of lbadan tap water after exposing it for 72 hours to the atmosphere.

The introduced plants were immediately held in position just below the water surface by fixing them to stakes using masking tape.

\section{Acclimatisation of test fish}

The fish were acclimatized for two weeks before introduction into the experimental aquaria. During the acclimatization and experimental periods, feeding was done twice daily. The fish were fed to satiation. During the acclimatisation period, stressed and dead fish were removed. The acclimatization was aimed at making them used to the new environment of the experiment (Okonji and Ewutanure, 2011).

\section{Physico - chemical parameters}

The source of water used for the experiment was from the University of Ibadan water supply. The water was first exposed in a 10,000 L capacity tank for about 72 hours to dechlorinate it before using it for the experiment to avoid chlorine toxicity (Association of Official Analytical Chemists, 1990). Water quality parameter monitored were Temperature, Nitrate, Nitrite, Alkalinity, pH, Dissolved Oxygen and Phosphate. Temperature was measured using mercury in glass thermometer, pH was determined by pH meter (Hanna model: HI-98107, USA), DO was done by Winkler's method, Phosphate and Alkalinity were determined titrimetrically, while Nitrate and Nitrite were analysed as described by Gupta, (2001).

\section{Collection and handling of blood samples}

Blood samples were drawn from near the anal fins and decanted into heparinised bottles containing EDTA solution to serve as anticoagulant for haematological determination (Culling, 1974). The needle was inserted at right angle to the ventral column of the fish and was gently palpated to collect the blood samples. The heparinised bottles containing the blood were then placed in an iced box to maintain moderate temperature during transportation to the laboratory for haematological analysis. Blood samples for serum analyses was decanted into plain bottles without EDTA and were allowed to stand until the blood clothed, the serum was then decanted for serological determination. Plasma was obtained from blood samples by centrifugation and then drawn into $1 \mathrm{~cm}^{3}$ plastic syringes, transferred into a universal bottle and kept in a refrigerator to be used for biochemical analysis (Dacie and Lewis, 1991). The standard haemocytometer was used in both erythrocytes and leucocytes counts using modified Hyme's dilution fluid (Blaxhall \& Daisley, 1973). The collected blood was introduced into an improved Neubaeur counting chamber and the cells counted using the microscope at $100 \times$ objective.

\section{Haematological and serum indices analysed}

Haematological indices analysed were packed cell volume (PCV), Haemoglobin ( $\mathrm{Hb}$ ), Red blood cells (RBC), White blood cells (WBC), Platelets, mean cell volume (MCV), mean cell haemoglobin (MCH), Mean cell haemoglobin concentration (MCHC), lymphocytes (Lym) and neutrophils (Neut), while serum indices were Total protein (TP), Albumin (Alb), Globulin (Glo), Potassium ion $\left(\mathrm{K}^{+}\right)$, Sodium ion (Na+), Creatinine (Cre), Aspartate Transaminase (AST), Alanintransaminase (ALT), Blood Urea Nitrogen (BUN) and Glucose, (Glu). Serum indices were determined by using commercial kits (Randox Laboratory Ltd., United Kingdom). Heavy metals were determined by using Atomic Absorption Spectrophotometer (AOAC, 1990). 


\section{Histopathological examination of liver and kidney of C. gariepinus juvenile}

Histopathological examination of the juvenile of $C$. gariepinus liver and kidney were carried out according to the method described by Drury et al., (1967) as follows: Livers and kidneys were harvested from Clarias gariepinus and preserved in bouin's solution for about 6 hours and later transferred to 10\% buffered formalin for about 12 hours (Culling, 1974). The organs were later dehydrated in graded ethanol (70 - 95\%) for 1 hour. (Dacie and Lewis, 1991). The dehydrated tissues were cleared in xylene and embedded in paraffin wax and left-over night after which they were sectioned in rotary microtome at $5 \mu \mathrm{m}$ thickness, placed on slides, stained with haemomatoxylin and eosin.

The photomicrograph of the sections were taken using electrical microscope (Model: B - 350 - Optika, Italy) and examined with the aid of atlas of fish histology.

\section{Statistical analysis}

Data collected were subjected to descriptive statistic and ANOVA at $\alpha_{0.05}$.

\section{RESULTS}

Mean Physico - chemical parameters; mean weight of Nickel measured in Plant; Fish; water; mean haematological; serum biochemical indices and histopathological of $C$. gariepinus juvenile are presented in Figure 1, Tables 1, 2, 3 and plate 1 , respectively. Water Temperature ranged from $24.53 \pm 4.23$ to $27.51 \pm 2.53$ in TWP3 and control; nitrite $(0.02 \pm 0.01,0.35)$; Nitrite $(0.01 \pm 0.01,0.03 \pm 0.01)$; Alkalinity $(21.53 \pm 4.14,75.05 \pm 0.05)$;

Phosphate - phosphorus $(21.09 \pm 0.87,89.51 \pm 4.63)$ in control and TWP1 while pH $(6.01 \pm 2.02,7.80 \pm 1.23)$ and DO $(3.01 \pm 0.61,4.56 \pm 0.91)$ in TW1 and TWP0 (control) respectively. The highest $(0.42 \pm 0.01 ; 0.29 \pm 0.01$ and $0.21 \pm 0.01)$ and least $(0.01 \pm 0.01 ; 0.02 \pm 0.01$ and 0.00$)$ levels of Nickel concentrations in P. aquilinium; C. gariepinus and water were obtained in TWP1 and TWPO (control), respectively.

Significantly highest $(25.71 \pm 0.43 ; 13.60 \pm 0.41 ; 14.02 \pm 0.01 ; 10.90 \pm 0.01 ; 7.52 \pm 0.50 ; 19.52 \pm 0.50 ; 9.51 \pm 0.52$; $33.55 \pm 0.51 ; 72.54 \pm 0.54$ and $39.72 \pm 1.02)$ and least $(9.53 \pm 0.50 ; 2.91 \pm 0.01 ; 6.74 \pm 0.43 ; 3.60 \pm 0.50 ; 3.62 \pm 0.55$; $14.51 \pm 0.50 ; 5.00 \pm 1.00 ; 31.82 \pm 0.25 ; 54.54 \pm 0.50$ and $34.59 \pm 0.31$ ) levels of PCV; Hb; RBC; WBC; platelets; MCV; $\mathrm{MCH}$; MCHC; Lym and Neut were recorded in TWPO (control) and TWP1 respectively.

Highest $(3.72 \pm 0.30 ; 1.39 \pm 0.10$ and $60.50 \pm 0.51)$ and least $(1.56 \pm 0.42 ; 0.90 \pm 0.10$ and $20.04 \pm 3.00)$ were recorded as mean TP; Alb and Glu respectively. Glo ranged from $0.53 \pm 0.20$ to $2.83 \pm 0.41 ; \mathrm{K}^{+}(14.01 \pm 1.00,31.52 \pm 0.50)$; Cre (1.10 $\pm 0.55,3.32 \pm 0.22)$; AST $(10.02 \pm 1.01,38.59) ; \operatorname{ALT}(14.54 \pm 0.61,66.51 \pm 1.50)$ and BUN $(1.67 \pm 0.62,4.91 \pm 0.10)$ in control and TWP1 while the mean $\mathrm{Na}^{+}$occurred as highest $(60.56 \pm 1.53)$ and least $(11.51 \pm 1.51)$ in TWP3 and TWP0 (control), respectively. 


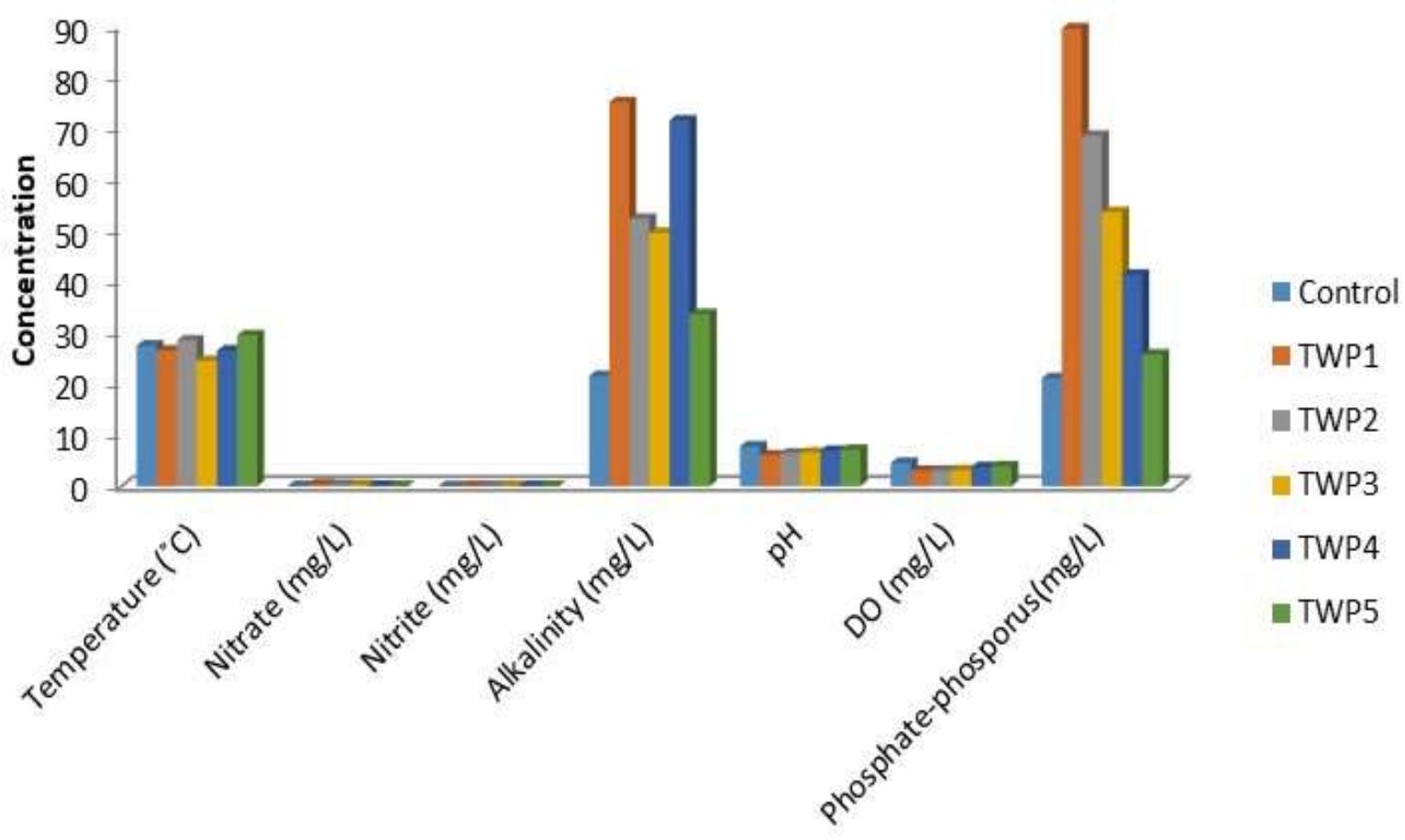

Physico-chemical parameters

Figure 1: Phyco-chemical parameters monitored during the experiment.

Note: Control $=$ TWP0, while TWP1 - TWP5 $=$ Treatments $1-5$.

Table 1: Mean weight of nickel obtained in plant, fish and water

\begin{tabular}{llll}
\hline Treatments & Plant $\left(\mathrm{mg} \cdot \mathrm{Kg}^{-1}\right)$ & Fish $\left(\mathrm{mg} . \mathrm{Kg}^{-1}\right)$ & Water $\left(\mathrm{mg}^{\mathrm{L}} \mathrm{L}^{-1}\right)$ \\
\hline TWP0 & $0.01 \pm 0.01^{\mathrm{c}}$ & $0.02 \pm 0.01^{\mathrm{b}}$ & $<0.01$ \\
TWP1 & $0.42 \pm 0.01^{\mathrm{a}}$ & $0.29 \pm 0.01^{\mathrm{a}}$ & $0.21 \pm 0.01^{\mathrm{a}}$ \\
TWP2 & $0.27 \pm 0.01^{\mathrm{b}}$ & $0.28 \pm 0.04^{\mathrm{a}}$ & $0.19 \pm 0.02^{\mathrm{a}}$ \\
TWP3 & $0.26 \pm 0.31^{\mathrm{b}}$ & $0.26 \pm 0.08^{\mathrm{a}}$ & $0.12 \pm 0.01^{\mathrm{b}}$ \\
TWP4 & $0.27 \pm 0.01^{\mathrm{b}}$ & $0.26 \pm 0.06^{\mathrm{a}}$ & $0.03 \pm 0.01^{\mathrm{c}}$ \\
TWP5 & $0.25 \pm 0.01^{\mathrm{b}}$ & $0.21 \pm 0.01^{\mathrm{a}}$ & $0.06 \pm 0.01^{\mathrm{c}}$
\end{tabular}

Note: Means with the same super script are not significantly different from each other at $p<0.05$ level of significance. TWP0 $=C$ Control, TWP1 - TWP5 = Treatments with varying concentrations of Nickel. 
Table 2: Mean haematological parameters of Clarias gariepinus juvenile determined during the experiment.

\begin{tabular}{ccccccc}
\hline Parameter & TWP0 & TWP1 & TWP2 & TWP3 & TWP4 & TWP5 \\
\hline PCV (\%) & $25.70 \pm 0.40^{\mathrm{a}}$ & $9.53 \pm 0.50^{\mathrm{c}}$ & $20.50 \pm 0.50^{\mathrm{a}}$ & $20.50 \pm 0.5^{\mathrm{a}}$ & $15.54 \pm 0.25^{\mathrm{b}}$ & $21.95 \pm 7.55^{\mathrm{a}}$ \\
$\mathrm{Hb}\left(\mathrm{g} \cdot \mathrm{dL}^{-1}\right)$ & $13.6 \pm 0.14^{\mathrm{a}}$ & $2.91 \pm 0.01^{\mathrm{c}}$ & $6.63 \pm 0.10^{\mathrm{b}}$ & $6.61 \pm 0.10^{\mathrm{b}}$ & $4.91 \pm 0.10^{\mathrm{b}}$ & $6.91 \pm 6.01^{\mathrm{b}}$ \\
RBC $\left(10^{6} \mathrm{~mm}^{-3}\right)$ & $14.0 \pm 0.11^{\mathrm{a}}$ & $6.74 \pm 0.43^{\mathrm{b}}$ & $8.33 \pm 0.24^{\mathrm{b}}$ & $8.51 \pm 0.03^{\mathrm{b}}$ & $6.19 \pm 0.11^{\mathrm{b}}$ & $8.45 \pm 0.61^{\mathrm{b}}$ \\
WBC $\left(10^{3} \mathrm{~mm}^{-3}\right)$ & $10.9 \pm 0.11^{\mathrm{a}}$ & $3.60 \pm 0.50^{\mathrm{b}}$ & $8.75 \pm 0.30^{\mathrm{a}}$ & $12.40 \pm 0.01^{\mathrm{a}}$ & $5.26 \pm 0.14^{\mathrm{b}}$ & $8.39 \pm 0.83^{\mathrm{a}}$ \\
PLT (g.L-1) & $7.50 \pm 0.50^{\mathrm{a}}$ & $3.62 \pm 0.55^{\mathrm{bb}}$ & $5.53 \pm 0.50^{\mathrm{a}}$ & $5.50 \pm 0.50^{\mathrm{a}}$ & $4.75 \pm 0.45^{\mathrm{a}}$ & $5.51 \pm 0.35^{\mathrm{a}}$ \\
MCV (fL) & $19.50 \pm 0.52^{\mathrm{a}}$ & $14.51 \pm 1.15^{\mathrm{b}}$ & $20.54 \pm 0.50^{\mathrm{a}}$ & $22.50 \pm 0.15^{\mathrm{a}}$ & $20.95 \pm 0.35^{\mathrm{a}}$ & $23.40 \pm 1.92^{\mathrm{a}}$ \\
MCH (Pg) & $9.50 \pm 0.53^{\mathrm{a}}$ & $5.00 \pm 3.00^{\mathrm{b}}$ & $7.51 \pm 0.50^{\mathrm{a}}$ & $7.53 \pm 0.52^{\mathrm{a}}$ & $7.05 \pm 0.45^{\mathrm{a}}$ & $8.57 \pm 0.95^{\mathrm{a}}$ \\
MCHC (g.dL-1) & $33.50 \pm 0.59^{\mathrm{a}}$ & $31.82 \pm 0.25^{\mathrm{a}}$ & $32.93 \pm 0.10^{\mathrm{a}}$ & $32.55 \pm 0.51^{\mathrm{a}}$ & $32.02 \pm 1.50^{\mathrm{a}}$ & $32.34 \pm 0.81^{\mathrm{a}}$ \\
Lym (\%) & $72.50 \pm 0.5^{\mathrm{a}}$ & $54.5 \pm 0.50^{\mathrm{b}}$ & $70.50 \pm 0.50^{\mathrm{a}}$ & $71.75 \pm 0.85^{\mathrm{a}}$ & $67.51 \pm 2.55^{\mathrm{a}}$ & $60.75 \pm 9.25^{\mathrm{a}}$ \\
Neut (\%) & $39.70 \pm 1.02^{\mathrm{a}}$ & $34.59 \pm 0.31^{\mathrm{b}}$ & $27.50 \pm 0.93^{\mathrm{b}}$ & $28.00 \pm 1.40^{\mathrm{b}}$ & $31.56 \pm 2.15^{\mathrm{b}}$ & $39.02 \pm 7.85^{\mathrm{a}}$
\end{tabular}

Note: Means with the same super script are not significantly different from each other at $p<0.05$ level of significance. PCV $=$ Packed cell volume, $\mathrm{Hb}=$ Haemoglobin, $\mathrm{RBC}=$ Red blood cell, $\mathrm{WBC}=$ White blood cells, PLT Platelet, $\mathrm{MCV}=$ Mean cell volume, $\mathrm{MCH}=$ Mean cell haemoglobin, $\mathrm{MCHC}=$ Mean cell haemoglobin concentration, Lym $=$ Lymphocyte, Neut $=$ Neutrophil, TWP0 $=$ Control, TWP1 - TWP5 = Treatments with varying concentrations of Nickel.

Table 3: Mean serum indices of Clarias gariepinus juvenile during the experiment.

\begin{tabular}{|c|c|c|c|c|c|c|}
\hline Parameter & TWPO & TWP1 & TWP2 & TWP3 & TWP4 & TWP5 \\
\hline $\mathrm{TP}\left(\mathrm{g} \cdot \mathrm{dL}^{-1}\right)$ & $1.56 \pm 0.42^{\mathrm{a}}$ & $2.66 \pm 0.20^{b}$ & $3.34 \pm 0.21^{a}$ & $3.72 \pm 0.3^{a}$ & $3.14 \pm 0.4^{c}$ & $3.11 \pm 0.3^{a}$ \\
\hline $\operatorname{Alb}\left(g \cdot d L^{-1}\right)$ & $0.94 \pm 0.10^{b}$ & $0.90 \pm 0.10^{b}$ & $1.24 \pm 0.1^{\mathrm{a}}$ & $1.23 \pm 0.10^{a}$ & $1.39 \pm 0.10^{a}$ & $1.20 \pm 0.10^{\mathrm{a}}$ \\
\hline Glo(g.dL-1) & $0.52 \pm 0.20^{b}$ & $2.83 \pm 0.41^{a}$ & $2.15 \pm 0.20^{a}$ & $2.31 \pm 0.10^{a}$ & $1.48 \pm 0.1^{a}$ & $1.31 \pm 0.10^{a}$ \\
\hline $\mathbf{K}^{+}\left(\right.$meq. L $\left.^{-1}\right)$ & $14.04 \pm 1.0^{b}$ & $31.52 \pm 0.53^{a}$ & $25.01 \pm 1.0 \mathrm{a}$ & $24.54 \pm 0.16^{a}$ & $12.57 \pm 0.15^{b}$ & $12.03 \pm 2.01^{b}$ \\
\hline $\mathrm{Na}^{+}\left(\right.$meq. $\left.\mathrm{L}^{-1}\right)$ & $20.63 \pm 0.16^{b}$ & $11.51 \pm 1.51^{\mathrm{c}}$ & $59.02 \pm 1.10^{a}$ & $60.56 \pm 1.52^{\mathrm{a}}$ & $30.06 \pm 2.00^{b}$ & $26.54 \pm 1.57^{b}$ \\
\hline Cre $\left(m g \cdot d^{-1}\right)$ & $1.10 \pm 0.55^{a}$ & $3.32 \pm 0.22^{\mathrm{a}}$ & $2.23 \pm 0.01^{a}$ & $2.47 \pm 0.1^{\mathrm{a}}$ & $1.23 \pm 0.1^{\mathrm{a}}$ & $1.29 \pm 0.03^{a}$ \\
\hline AST(IU.L-1) & $10.02 \pm 1.01^{c}$ & $38.54 \pm 0.50^{\mathrm{a}}$ & $37.04 \pm 1.00^{\mathrm{a}}$ & $34.09 \pm 0.25^{a}$ & $19.02 \pm 1.40^{b}$ & $17.06 \pm 1.00^{b}$ \\
\hline $\operatorname{ALT}\left(I U . L^{-1}\right)\left(I U . L^{-1}\right)$ & $14.54 \pm 0.61^{c}$ & $66.54 \pm 1.50^{\mathrm{a}}$ & $59.04 \pm 1.00^{a}$ & $61.50 \pm 0.5^{a}$ & $27.04 \pm 1.10^{b}$ & $25.07 \pm 1.00^{b}$ \\
\hline BUN (mg.dL $\left.{ }^{-1}\right)$ & $1.67 \pm 0.16^{a}$ & $4.91 \pm 0.01^{a}$ & $2.44 \pm 0.01^{a}$ & $2.12 \pm 0.20^{a}$ & $2.22 \pm 1.00^{a}$ & $2.20 \pm 0.04^{b}$ \\
\hline Glu (g.dL-1) & $60.59 \pm 0.15^{\mathrm{a}}$ & $20.00 \pm 3.10^{b}$ & $53.05 \pm 1.00^{a}$ & $52.01 \pm 2.40^{a}$ & $27.09 \pm 3.01^{b}$ & $21.01 \pm 1.00^{b}$ \\
\hline
\end{tabular}

Note: Means with the same super script are not significantly different from each other at $p<0.05$ level of significance. TWP0 $=$ Control, TWP1 - TWP5 $=$ Treatments with varying concentrations of Nickel, $\mathrm{TP}=$ Total protein, $\mathrm{Alb}=$ Albumin, $\mathrm{Glo}=$ Globulin, $\mathrm{K}^{+}=$Potassium, $\mathrm{Na}^{+}=$Sodium, Cre $=$Creatinine, $\mathrm{AST}=\mathrm{Aspartate}$ Aminotransferase, $\mathrm{ALT}=$ Alanine Amino Transferase, $\mathrm{BUN}=$ Blood Urea Nitrogen, Glu = Glucose 

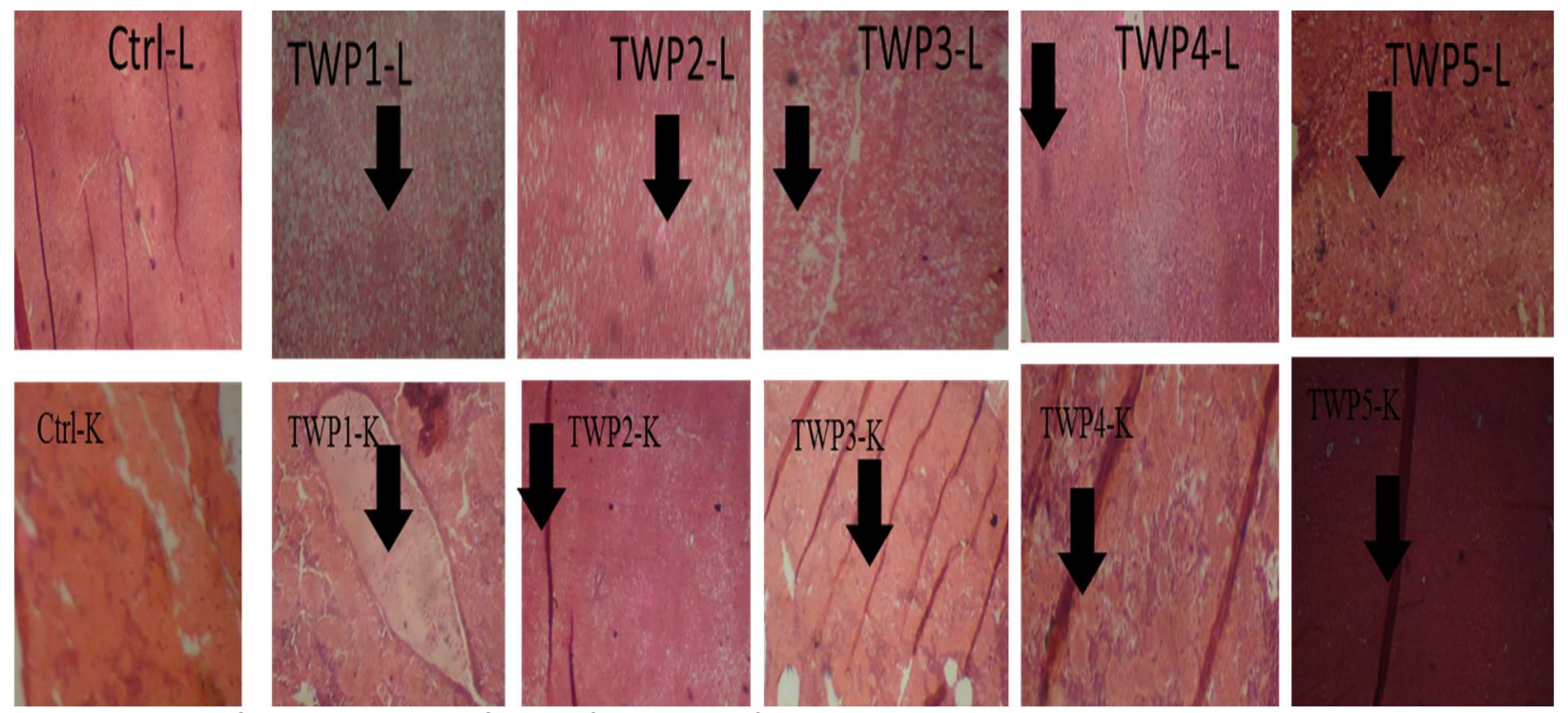

Plate 1: Livers (Ctrl-L) and kidney (Ctrl-K) of the control fish, T1WP-L to T5WP-L and TWP1-K to TWP5-K subjected to nickel toxicity. Control (Ctrl - L and Ctrl $-K$ ) with normal condition of the fish liver and kidney (X400) respectively.

T1WP-L to T3WP-L showed severe diffused vacuolar degeneration in liver of the fish but it is more severe in T1WP-L (X400) while T4WP-L and T5WP-L: Shows mild vacuolar degeneration in liver of the fish (X400). Kidney of fish TWPK - T5WP-K) subjected to nickel toxicity shows severe congestion in blood sinusoids (X400) (TWP1-K), T2WP-K: Mild vacuolar degeneration in the renal tubules (x400) while T3WP-K to T5WP-K: Mild necrotic degeneration in the renal tubules (x400)

\section{DISCUSSION}

Nickel is known to be an essential element in plants and animals but at high concentration, it exerts adverse effects by producing structural damage that affects the growth, development and survival of the fish (Olaifa and Ewutanure, 2018). Concentration of $\mathrm{Ni}$ recorded were in the order plant $>$ fish $>$ water. The highest concentration of $\mathrm{Ni}$ was recorded in Pteridium aquilinum which could be linked to its phytoremediation potential (Pilon - Smits, 2005). This could be responsible for its low concentration in water (Kori-Siakpere and Ubogu, 2008). But the concentration recorded in the fish indicated that it had bioaccumulated considerable quantity (WHO, 2010). Haemo - concentration and haemo dilution have been reported after the exposure of Coli fasciatus to nickel as a toxicant (Abouldroos et al., 2006). Haematological and serum biochemical indices obtained during the exposure of $\mathrm{C}$. gariepinus juvenile to nickel toxicity showed significant variation among treatments with increasing concentration. These results agree with Kori-Siakpere et al., (2006) when Heteroclarias juveniles were exposed to zinc as toxicant.

Red blood cells contain a protein called haemoglobin which carries oxygen from the lungs to all parts of the body. They are produced from the bone marrow and are transferred into the blood. Compare with control (TWP0), low PCV (haematocrit) level recorded in TWP1 - TWP5 signifies low number of red blood cells which could be as a result of the contact with toxicant (Gupta and Srivastava, 2006). Without P. aquilinum, impact of Nickel toxicity on the C. gariepinus juvenile would have been more severe (Khan et al., 2012). This could induce an anaemic condition but NAS, (2011) reported an increase in haematocrit levels in different fish species after zinc treatment. Such an increase could be associated with the increase in the size of erythrocytes as being demonstrated for chromium and zinc treated rainbow trout (USEPA, 2007). 
Kori-Siakpere et al., (2006) recorded an increase in red blood cells when C. gariepinus was exposed to zinc and attributed this elevation to blood cell reserve combined with cell shrinkage because of osmotic alterations of blood by the action of heavy metals. Swelling of the red blood cells may be due to an increase in protein and carbon dioxide in blood (USEPA, 2011).

\section{Red blood cell index}

Fish mean corpuscular volume (MCV) is a measure of the average size of the red blood cells, while MCHC determines the average amount of haemoglobin in a group of red blood cells (Olowu et al., 2012). Liver disease is a common cause of increased MCV which may be due to intake of toxins (Olowu et al., 2010). A decrease in MCHC level in fish blood could be linked with unfavourable aquatic environmental quality (Ewutanure and Olaifa, 2017). This could cause oxygen depletion in all tissues thereby placing the fish in an anoxic condition which could eventually threaten their survival (Gupta and Srivastava, 2006).

A high MCHC means that haemoglobin is excessively concentrated and this could occur when red blood cells break down as a result of contact with toxicants (Olowu et al., 2012). A low MCHC concentration in fish implies haemoglobin concentration in red blood cells is low. High $\mathrm{MCH}$ is a sign that the red blood cells in the experimental fish are not dividing by the right process which may cause anaemic condition (Olowu et al., 2012).

\section{White blood cells (WBC)}

Physilogically, WBC helps the fish body to fight against infection and diseases (Olaifa and Ewutanure, 2018). The WBC comprises lymphocytes, monocytes and granulocytes (eosinophils, basophils and neutrophils). White blood cell count might increase due to the presence of toxins, infection, bone marrow abnormality, chronic lung disease and inflammatory reactions (Kori - Siakpere et al., 2006). The WBC in response to chemical contaminants might encounter infections. Therefore, increasing or decreasing white blood cells are normal reactions to toxic chemicals such as nickel (Outridge and Scheuhammer, 2007). The increase in number of white blood cells may be due to the bio - accumulation of Nickel in the liver and kidney of the fish.

\section{White blood cells (WBC) index}

High lymphocyte blood levels in fish blood shows that it is fighting an inflammatory condition or infection. Chronic lymphocyte counts could indicate a possible infection as a result of stress (Olaifa and Ewutanure, 2018). Neutrophils are generated from the bone marrow in fish before being released into the bloodstream to be transported to where they are needed in the body (Olowu et al., 2010). High concentration of neutrophils in the fish blood is known as neutrophilia. It signifies that the fish has an infection (Osman et al., 2010). Neutrophils rejuvenate damaged tissues and heal infections (Maheswaran, et al., 2008). Neutrophil blood levels raise in response to healing infections, injuries and stress.

Increase in concentrations of haematological parameters observed could be due to the increase in the level of corticosteroid hormones whose secretion is a non - specific response to any environmental stressor (Xu et al., 2009). Abnormal increase in platelet level could cause a condition called thrombocytosis, while too little can lead to situation referred to as thrombocytopenia (Ghazaly, 2011). Higher concentration of platelet could lead to an increase in blood clotting in fish (FAO, 2004). Significant changes were observed among various haematological and serum biochemical profiles at different concentrations of nickel. The changes in haematological and serological indices of the fish may be closely associated with the presence of nickel as a contaminant (Ololade and Oginni, 2010). The various concentrations of nickel and the duration of exposure of the fish can cause an irreversible alteration in the homeostatic condition (Maheswaran et al., 2008). High values of nickel determined in plants, fish and water compared with the control are indication that nickel was bio - accumulated highest in plant followed by fish and least in water. The implication of this is that, $P$. aquilinum have reduced greatly the concentration of nickel that would have been available in the water as toxicant to the $\mathrm{C}$. gariepinus juvenile. 
No mortality was observed in the current study but histopathological results revealed liver and kidney alterations and this is in agreement with the observation made by Oluwo et al. (2012) who concluded from the results of their experiment that though mortality may not be observed when fish are exposed to heavy metal toxicity, there could be interference with various physiological processes and health of the experimental animal might be challenged. The high concentration of nickel observed in Pteridium aquilinum, fish and water compare with control could be the reason for zero mortality (Khan et al., 2012). The quantity of nickel present in the fish would have been higher which could have led to high mortality rate of the experimental fish. This result is in consonance with Chotu et al., (2009). The ability of P. aquilinum to bio - accumulate nickel, withstand and survive in many areas with a mild climate and fast-growing potential has created a possibility for it to be used as a phytoremediation plant (Bes and Mench, 2008). It was also observed that the growth of the experimental fish during the study was stunted. Hence, it was stated that diet and mediums containing nickel sulphate, nickel chloride and nickel carbonate caused reduced growth and disruptions of food intake as a result of physiological changes in the internal organs of an organism (Sigel and Sigel, 2007).

The observed increase in serum parameters with decreasing concentrations of nickel could also be attributed to the lysing of erythrocytes. Similar reductions have been reported by Ololade and Oginni, (2010) when they exposed fish to nickel toxicity under laboratory conditions. Hence, the significant reduction in these parameters is an indication of severe anaemic condition caused by exposure of the experimental fish to nickel poisoning in the water (USPH, 2010). Such increase in haematocrit values was attributed to increase in the size of the erythrocytes as demonstrated for Heteroclarias (Kori-Siakpere, 2006). Total protein test determines the concentration of protein in the fish blood (Bani et al., 2007). The presence of protein is very essential for proper functioning and growth of the body's cells and tissues of animals (Khan and Moheman, 2006). The measurement of total protein helps to detect kidney and liver diseases (Ewutanure and Olaifa, 2018). Albumin prevents fluid from spilling out of blood vessels. Highre protein in the fish blood can be a sign of chronic infection or inflammation as a result of exposure to toxic substances (NAS, 2011).

It can also be a sign of a bone marrow disorder as a result of toxicity (White and Karley, 2010). Low A/G ratio: This might be the sign an autoimmune disorder, Low total protein level could be as a result of liver and kidney diseases (Abouldroos, et al., 2006). Albumin is a very common protein found in the blood with different functions, but is produced in the liver only (Chris 2010). Decrease in Albumin level than normal could cause liver cirrhosis (Ewutanure and Olaifa, 2018). Researches have revealled that increased globulin level is associated with an increased risk of disease and death as a result of exposure to stress (Ololade and Oginni, 2010). Globulin is produced in the liver by the body immune system and helps in liver functions, blood clotting and protection against infections (NAS, 2011).

Sodium helps fishes to maintain normal blood pressure, water and electrolyte balance of the body, nerves, muscles and regulates fish body's fluid balance (Oluwo et al., 2012). High concentration of $\mathrm{Na}(85 \%$ ) in the body of fish is located in blood and lymph fluid, while parts of the level of $\mathrm{Na}$ in the fish body is controlled by aldosterone hormone secreted by the adrenal glands - which regulates the secretion of sodium and determines when the kidneys should hold or pass it in the urine (Oluwo et al., 2010). Potassium maintains the normal and regular heartbeat. It facilitates the transportation of nutrients into and waste products out of cells (Chhotu et al., 2009).

Potassium $(K)$ is the most abundant inorganic cation and it supports optimal growth of flora and fauna (White and Karley, 2010). It activates enzymes secretion, transports sugar and enhances photosynthesis. Low level of potassium in fish blood is associated with adrenal gland disorders. A low potassium level can cause weak muscles, abnormal heart beats and paralyses in fish. Creatinine is a waste product that is formed when creatine located in the fish muscles breaks down, while elevated creatinine level indicates impaired kidney function or kidney disease as a result of contact with toxic substances (Chris, 2010). As the kidneys become impaired, the creatinine concentration in the blood rises due to inadequate clearance of creatinine by the kidneys, while the excessive rise in the concentration of creatinine indicates possible failure of the kidneys (Alaa, 2010). 
High levels of ALT in fish may indicate liver damage from poisoning, infection and cirrhosis due to the presence of toxins (NAS, 2011). Increase levels of ALT and AST in liver are associated with disorder of its functions that cause rapid death of numerous liver cells. The degree of increase in liver enzymes can occur in conditions when the experimental fish is subjected to a very high level of toxicant (Gupta and Srivastava, 2006). The ALT test is done to determine whether an organism has liver damage or failure. It is an enzyme situated in the liver that convert proteins into energy for the liver cells. Under normal situation, these enzymes are mainly located inside the cells of the liver. But when the liver is challenged, damaged or injured due to environmental stressors, they then spill into the blood stream indicating liver disease (Abouldroos, et al., 2006).

On a general note, a high level of blood urea nitrogen may signify improper functioning of the kidneys (Khan et al., 2008). The concentration of glucose in the body of fish is regulated by different body mechanisms but the liver releases glucose into the blood for nourishment of insufficient glucose level (Oluwo et al., 2012). This process is called gluconeogenesis. In chronic liver disease, this function of the liver could be altered as a result of contact with favopurable conditions leading to a decrease in glucose levels (Oluwo et al., 2010).

\section{Histopathology}

Nickel affects tissue respiration leading to death of living organisms by hypoxia (Ewutanure and Olaifa, 2017). This induces changes in liver, kidney, vein and heart of the fish. The exposure of fish to heavy metal toxicity such as Nickel could cause significant alterations in its physiological organs (Chris, 2010). Fish muscle is believed to be the water exchange tissue with blood. The Ctrl $-\mathrm{L}$ and $\mathrm{Ctrl}-\mathrm{K}$ show the normal histological structures of the liver and the kidney, respectively. Remarkable structural changes were detected in the liver and kidney harvested from the experimental fish. Significant differences in the degree of such changes were recorded according to the various levels of Nickel concentrations and the physiological alterations were more visible in the treatment with highest concentration of Nickel (TWP1 - L and TWP1 - K).

The photomicrograph of the normal liver shows the parenchyma cells arranged to form a lattice network. The interspaces are the sinusoid of thin strip with sparse connective tissue (Alaa et al., 2010). The sinusoids made continuous communication as seen converging into the central vein. The hepatopancrease was clearly distinguished between the liver tissues. Changes in liver of the examined fish also included irregular arrangements of hepatocytes, vacuolation and necrosis of the cytoplasm (Oshode et al., 2008).

\section{CONCLUSION}

The results from this experiment showed that the exposure of Clarias gariepinus juvenile to Nickel toxicity negatively impacted its physiological compositions, while the level of Ni in Pteridium aquilinum implied that it bioaccumulated the highest concentration of $\mathrm{Ni}$ compared with the water and fish samples analysed. This shows that $\mathrm{P}$. aquilinum has a phytoremediation potential. 


\section{REFERENCES}

1. Aboulroos, S. A; Helal, M. I. D. and Kamel, M. M. 2006. Remediation of $\mathrm{Pb}$ and $\mathrm{Cd}$ polluted soils using in situ immobilization and phytoextraction techniques. Soil Sediment Contaminants, 15: 199 - 215.

2. Alaa, G. M. Osman, Abd - El - Baset, M. Abd El Reheem, Khalid Y. AbuelFadl, Ali G. GadEl-Rab, 2010. Enzymatic and histopathologic biomarkers as indicators of aquatic pollution in fishes. Journal of Environmental Health, 2.11: 1302-131. http://dx.doi.org/10.4236/ns.2010.211158

3. Alan, R.; Smith, K.; M.; Pryer, Eric, S.; Petra, K.; Harald, S. and Paul, G. W. 2006. Fern classification. Plant Physiology, 55 (3): 705-731.

4. Association of Official Analytical Chemists (AOAC), 1990: Journal of Official Method of Analyses 8 (1): 551 573.

5. Bani, A., Echevarria, G., Sulçe, S., Morel, J.L., Mullai, A. 2007. In-situ phytoextraction of Ni by a native population of Alyssum murale on an ultramafic site (Albania). Plant Soil, (2007) 293:79-89. DOI 10.1007/s11104-007-9245-1.

6. Barac, T, Weyens N, Oeyen L, Taghavi S, van der Lelie D, Dubin D, Spliet M, Vangronsveld J (2009) Field note: hydraulic containment of a BTEX plume using poplar trees. International Journal Phytoremediation 11:416-424.

7. Bes, C. and Mench, M. 2008. Remediation of copper-contaminated topsoils from a wood treatment facility using in situ stabilisation. Environmental Pollution 156:1128-1138.

8. Blaxhall, P. C. and Daisley, K. W. 1973. Routine haematological methods used in fish blood. Journal of Fish Biology, 5: 77.

9. Chhotu, D. Jadia and Fulekar, M. H. 2009: Phytoremediation of heavy metals: Recent techniques. African Journal of Biotechnology, 8 (6): 921-928.

10. Chris, O. N. 2010. Trends in phytoremediation of toxic elemental and organic pollutants. African Journal of Biotechnology, 9 (37): 6010-6016.

11. Culling, C.F.A. 1974. Handbook of histopathological and histochemical techniques. Butterworth and company publisher, Britain. 1 - 197.

12. Dacie, J.V. and Lewis, S.M. 1991. Practical haematology. $6^{\text {th }}$ Edition, New York: Churchill. 22.

13. Drury, R.A.M., Wallington, E.A. and Roy, C. 1967. Carleton histological techniques, Oxford University Press. $10-150$.

14. Ewutanure, S. J. And f. E. Olaif. (2017). Length - weight relationships and condition factor of Clarias gariepinus from Gbalegbe River, Delta State, Nigeria. Proceedings of the 32nd Annual National Conference of Fisheries Society of Nigeria held at Nnamdi Azikiwe University, Awka, Anambra State. 23rd -28th October, 2017. $329-332 \mathrm{Pp}$.

15. Food and Agricultural Organization (FAO) of the United Nations 2004. Manual of methods in aquatic environment research. Part 4. Basis for selecting biological tests to evaluate marine pollution. FAO Fisheries Technical Paper 164. 31Pp.

16. Ghazaly, K. S. 2011. Sub-lethal effects of nickel on carbohydrate metabolism, blood and mineral contents of Tilapia nilotica. Water, Air, and Soil Pollution, 64:525-532.

17. Gupta, P. and N. Srivastava, 2006. Effects of sublethal concentrations of zinc on histological changes and bioaccumulation of zinc by kidney of fish Channa punctatus (Bloch). Journal of Environmental Biology 27: 211-215.

18. Gupta, P. K. 2001. Methods in environmental analysis: Water, Soil and Air. AGROBIOS (India) Publisher. Pp. 1- 408.

19. Khan HA, Arif IA, Al Homaidan AA (2012) Distribution pattern of eight heavy metals in the outer and inner tissues of ten commonly used vegetables. Int J Food Prop 15:1212-1219..

20. Khan S, Cao Q, Zheng YM, Huang YZ, Zhu YG (2008) Health risks of heavy metals in contaminated soils and food crops irrigated with wastewater in Beijing, China. Environ Pollut 152:686-692. 
21. Khan SU, Moheman A (2006) Effect of heavy metals (cadmium and nickel) on the seed germination, growth and metals uptake by chilli (Capsicum frutescens) and sunnower plants (Helianthus annuus). Pollut Res 25:99-104.

22. Kori - Siakpere, O. and Ubogu, E. O., 2008: Sublethal haematological effects of zinc on the freshwater fish, Heteroclarias sp. (Osteichthyes: Clariidae). African Journal of Biotechnology. 7(12): 2068 - 2073. www.academicjournals.org/AJB.

23. Kori - Siakpere, O.; Ake J.E.G.; Avworo, U.M. 2006. Sub-lethal effects of some selected haematological parameters of Heteroclarias (A hybrid of Heterobranchus bidorsalis and Clarias gariepinus). International Journal Zoological Resources, 2: 77-83.

24. Maheswaran, R.; Devapan, A.; Muralidharan, S.; Velmurugan, B. and Ignaeimuthu, S. 2008. Haematological studies of fresh water fish, Clarias batradrus (L) exposed to mercuric chloride. International Journal of Invertebrata Biology, 2(1): 49-54.

25. National Academy of Sciences (NAS). (2011). Medical and biological effects of environmental pollutants. Nickel. National Research Council, National Academy of Sciences, Washington, D.C., Pp 220 - 277.

26. National Research Council of Canada (NRCC). 2011. Effects of nickel in the Canadian environment. Publication No. NRCC 18568. Publications, NRCC/CNRC, Ottawa, Canada. Pp $300-352$.

27. Okonji, V. A. and Ewutanure, S. J. 2011. The effects of daily and alternate feeding days on the growth rate of C. gariepinus fingerlings fed with commercial feed (coppens). Nigeria Journal of Agriculture, Food and Environment, 7 (3): 33 - 34 .

28. Olaifa, F.E. and Ewutanure, S.J. 2018. Haematological Response of Clarias gariepinus (Burchell, 1822) juveniles to Nickel toxicity. In: Emerging Issues in Sustainable Forest Management: Experiences and Lessons for Nigeria. Proceedings of the 40th Annual Conference of the Forestry Association of Nigeria held in Lagos, Lagos State on 12-16th March, 2018. Editors: Akinwole, A.O., Adekunle , V.A.J.,Ogunsanwo, O.Y. pp 807817.

29. Ololade and Oginni, 2010. Toxic stress and haematological effects of Nickel on African catfish, Clarias gariepinus, fingerlings. Journal of Environmental Chemistry and Ecotoxicology, 2(2): $014-019$.

30. Olowu, R.A., C.T. Onwordi, A.A. Denloye, M.O Osundiya, N.O. Adebayo, M.S. Owolabi, O.O. Tovide, B.A. Moronkola, O.A. Omoyeni, Ajuwon, O. R. 2012. Heavy Metals in Oreochromis niloticus (Linnaeus, 1758) (Persiformes: Cichlidae), Ictalurus punctanus (Rafinesque, 1818) (Suliriformes: Ictaluridae) and Bottom Sediments from Lagos Lagoon Proximal to Egbin Power Plant, ljede, Ikorodu, Lagos Nigeria". Research Journal of Environment and Earth Sciences 4(3): 237 - 243.

31. Olowu, R.A., O.O.; Ayejuyo, G.O. Adewuyi, A.O Babatunde, I.A. Adejoro, A.A.B, Denloye, and Ogundajo, A. L. 2010. Heavy metals in fish tissue, water, sediment from Epe and Badagry lagoons Nigeria". E-Journal of Chemistry 7(1): $215-221$.

32. Oshode, O. A.; Bakare, A. A.; Adeogun, A. O.; Efuntoye, M. O. and Sowunmi, A. A. 2008. Ecotoxicological assessment using Clarias gariepius and microbial characterization of leachate from municipal solid waste landfill. International Journal Environmental Resource, 2(4): 391 - 400.

33. Osman, A.G.M., Al-Awadhi, R.M., Harabawy, A.S. and Mahmoud, U.M. 2010. Evaluation of the Use of Protein Electrophoresis of the African Catfish Clarias gariepinus (Burchell, 1822) for Biomonitoring Aquatic Pollution. Environmental Research Journal, 4, 235-243.

34. Outridge, P. M.; and A. M. Scheuhammer, A. M. 2007. Bioaccumulation and toxicology of nickel: implications for wild mammals and birds. Environmental Reviews, 1:172-197.

35. Pilon - Smits, E. 2005. Phytoremediation, Annual Review. Plant Biology, 56: 15 - 39.

36. Reish, D. L. and Oshida, P. S. 1987. Manual of methods in Aquatic Environment Research, part10. Short term Static Bioassays. FAO. Fisheries Technical paper NO.247. Rome. Pp 1 - 62Pp.

37. Sigel, H., and A. Sigel 2007. Metal ions in biological systems. Nickel and its role in biology. Marcel Dekker, New York. Environmental Pollution, 23: 400 - 488. 
38. U. S. Environmental Protection Agency (USEPA). 2008. Ambient water quality criteria for nickel. EPA Report 440/5-80-060. Pp. $189-206$.

39. U. S. Environmental Protection Agency (USEPA). 2009. Drinking water criteria document for nickel. EPA Report 600/X-84-193-1. Pp. 30 - 64.

40. U. S. Environmental Protection Agency (USEPA). 2011. Preliminary investigation of effects on the environment of boron, indium, nickel, selenium, tin, vanadium and their compounds. Volume III. Nickel. U.S. Environmental Protection Agency Report 560/2-75-005c. Pp. 40

41. U. S. Public Health Service (USPHS). 2010. Criteria for a recommended standard occupational exposure to inorganic nickel. U.S. Department of Health, Education, and Welfare, Public Health Service, Center for Disease Control, National Institute for Occupational Safety and Health. DHEW (NIOSH) Publication No. 77 164. Pp. 1 - 282.

42. U. S. Public Health Service (USPHS). 2011. Toxicological profile for nickel Cleaning up the Nations waste sites: Market and Technology Trends. EPA/542/R-96/005. Office of Solid Waste and Emergency Response, Washington, DC., Pp. 10 - 12.

43. USEPA, 2007. Heavy metals and their impacts on animals and man. Toxicological profile for cleaning up heavy metals from contaminated sites. Office of Research and Development, Cincinnai, OH. Pp. $97-234$.

44. White, P. J., and Karley, A. J. 2010. Potassium Cell Biology of Metals and Nutrients. Berlin: Springer, 199224.

45. WHO, 2008. Bacterial inoculants of forage grasses enhance degradation of 2-chlorobenzoic acid in soil. Environmental Toxicology Chemistry, 16: 1098 - 1104.

46. WHO, 2010. Nickel and phytoremediation in the aquatic environment. Aquatic Science, 5: $1-5$.

47. World Health Organization (WHO). 2008. Nickel Environmental Health Criteria, Nature, 4: $389-383$.

48. Xu, Q. S.; Ji, W. D.; Yang, H. Y.; Wang, H. X.; Xu, Y.; Zhao, J. and Shi, G. X. 2009. Cadmium accumulation and phytotoxicity in an aquatic fern, Salvinia natans (Linn.). Acta Ecologica Sinica, 29: 3019 - 3027. 